Romanelli, S. (2015). Manuscripts and translations: Spaces for creation. Linguistica Antverpiensia, New Series: Themes in Translation Studies, 14, 87-104.

\title{
Manuscripts and translations: Spaces for creation
}

\author{
Sergio Romanelli \\ Universidade Federal de Santa Catarina-CNPq, Brasil \\ sergioroma70@gmail.com
}

In this article I present my research on Genetic Criticism applied to translation carried out in the past 10 years - partly during my doctoral studies and my post-doctoral internship in Belgium. In both cases, I associate the methodology of Genetic Criticism, focused on artistic creation, with the documentation regarding the process of translations. In the first case, I examine the process of translating Emily Dickinson's poems into Italian by the poet and translator Rina Sara Virgillito; in the second case, I look into the process of translation from various classic and modern languages into Portuguese by the Emperor of Brazil, Dom Pedro II. The objective of both studies was to establish, within the new paradigm of systemic thinking, a true transdisciplinarity between the genesis of texts (text genetics) and Translation Studies. I hope that the former will be able to assist in the study of the creative process of the translator - here understood as a true authoring process - and that the latter will be able to provide speculative tools for a transversal methodology in search of a theory of its own. Finally, I consider both the manuscripts and the translational activity as spaces for creation, for the effective new signification of signs as a consequence of their unstable nature.

\section{Manuscripts and translation: Genetic criticism and descriptive translation studies}

I start from the premise that both the manuscript - whether a printed or a digital version - and the translation are creative spaces, text labs of the continuous renewal of signs, be they graphical or pictorial. As a matter of fact, just like the manuscript, the space of translation is a space of transformation and of disclosed or potential possibilities, either stored in drawers and the files of the author/translator or, perhaps, rescued through a new act of creation. The manuscript is the living space of the work in which the fixed signs in the edited text can still merrily roam free, constructing, in the opposition and convergence of syntagmatic and paradigmatic axes of the sheet, the possibilities of language and literary creation. The space of translation equals the space of the manuscript because by means of a translation the source text and its architecture are 
re-encoded, dismantled and reworked, giving these forgotten signs a new life, a creative reincarnation, which takes place in new shapes, but, again, in unfinished and open versions. I would say that both in the manuscript of a literary work (or in its drafts, sketches or unfinished versions) and in translations we see the potential text. By potential is meant power, for, in fact, more than in the edited text, it is in these uncensored spaces that we find the true poetic forces of a creative discourse.

The genetic analysis of this privileged space of creation - the translation manuscript - has already been approached in Brazil in the past few years by the research group I co-ordinate, the NUPROC (Centre for Studies of the Creative Process www.nuproc.cce.ufsc.br), at the Federal University of Santa Catarina. The perspective of this research group is absolutely transdisciplinary. Its central thesis is the defence of the importance of genetic analysis in Translation Studies. Such analysis examines translation manuscripts in order to expound the creative process of the translator seen as a true authoring process that serves to demystify deeply rooted stereotypes about the work of the translator. These include: "Is translation a profession or just a job?", "And what kinds of translation are there?", "Should translations be only technical?", "Is the translator really an author?" and "How can the translator consolidate his perception of the world with new signs?". The answers to these questions can, in my view, be answered only if we a take a deep look behind the scenes of creation, even a look at the translator. It seems difficult, if not impossible, to analyse the translator's thinking process from the perspective of edited texts which disregard the translator's role, rendering the translator invisible, and denying the role of the paratexts (in the absence of his or her name on the cover, for example, of his or her biography, etc.). And deny the role of the edited texts which censor and shape, brooding with rules and constrictions of various sorts - editorial, political, poetic, social and cultural - the translator's creativity. Genetic Criticism (GC) therefore fills a methodological gap and assists in the analysis and reading of these manuscripts from a perspective never seen before.

When I begin tackling the analysis of translation manuscripts, I usually ask "What is 'to create'?", "What is 'to create' from the point of view of translation?". An initial answer, in my view, is that to translate is "to create" and not "to re-create", as is often repeated without much substantiation in conferences, in doctoral dissertations, in classes and so forth. The concept of translation as re-creation only reproduces, under the disguise of an aura of linguistic and conceptual originality, the old prescriptive view which Translation Studies is attempting to challenge and to overcome: the view that a translation is a secondary text in relation to the original. Despite theoretical discussions and advances in the rethinking of what translation is, we still hear, not only among the laity but also within academia - students, professors, and researchers - that translation is not creation, that the target text does not possess an 
Manuscripts and translations: Spaces for creation

autonomous status with respect to the source text and to its author, since the translator, in this stereotyped vision, is not regarded as an author. Therefore I ask: How, then, can GC help to unveil this unique creative process of translation, highlight what is within, and show that the mechanisms of the act of translation are also the mechanisms of the act of writing?

In my view, the act of translating is a creative process and, as such, it is part of a communicative process in which the translator chooses, decides, and selects from among a number of possibilities and constraints. The question is not only to know how, but also to know why the translator makes certain choices and why he or she discards other options; it is to try to understand which elements contribute and/or interfere in this problem-solving process. How can we follow this process with no records, no marks, no indexes, if all this complex pathway is erased and cleared of all other elements when the translated text is edited? According to Hermans (1999, p. 23), the edited translation is only one stage in this creative process, one which resembles a game of chess.

As one proposes to study the translation process, the methodology of GC comes to one's aid as it tries to reconstruct, by approximation, this path of cumulative decisions which previously could only be guessed at from a reading of the edited text.

When considering a translation as an autonomous text, the Descriptive Translation Studies (DTS) that emerges within a specific cultural and social context has also proposed that the norms and strategies that guided the creation of this new text be reconstructed. But the most challenging task is to try to reconstruct the invisible mental process that takes place in the mind of the translator. The fundamental question is to know how to gain access to the black box that is the mind of the translator.

In my view, GC can assist DTS in this search. But in order really to be able to reconstruct this peculiar creative process of the translator, the dossiers to be studied should include not only the translator's manuscripts, but also the books he or she read and the notes written in the margins which record the dates of successive readings. Also to be studied are the catalogue of the translator's personal library and any other traces left: letters, diaries, digital archives, interviews, notes, drawings, etc.

In fact, as a translator begins to think about which author or book to translate, he or she already demonstrates, implicitly or explicitly, ownership of some knowledge of translation. By applying the methodology of DTS, on the other hand, the researcher is then able to retrace the path back to the beginning of the translation process. In other words, by departing from the translation, the researcher can return to the strategies and the norms (and not just the linguistic norms) that conditioned the translator(s). When I analyse a translation, I use the hypothetical scheme devised by José Lambert and Hendrik van Gorp (1985) and later taken up by Gideon Toury (1995). 
From what has been presumed to this day, it is safe to say that GC and DTS share the same paradigm, that is, a similar method and, above all, theoretical principles that work in perfect harmony. Both make use of an inductive research methodology. GC examines the manuscript with the aim of reaching "[...] possible conclusions related to a theory of creation" [[...] possíveis conclusões relativas a uma teoria da criação.] (Salles, 1992, pp. 33-34). The latter, DTS, likewise, does not depart from an $a$ priori assumption of the pseudo-objective characteristics of a hypothetically "good translation"; it departs instead from empirical data of actual translations in order to try to reassemble, through the analysis of texts, the laws and constraints experienced by the translator along the path of the translation process. Because of the similar epistemology of these two approaches, it seems only logical to bring them together for the first time in applying them to the study of translation manuscripts. The main foundation of this research paradigm is the concept that, for genetic critics, the published work and the draft are considered one single object. The organization of this very heterogeneous material is the first task of the geneticist. So, once the genetic dossier - also called the prototext - of a given author is established, the researcher, at the end of the process of making it readable, should organize it by engaging in the description and transcription of documents.

\section{First case: Virgillito translating Dickinson}

The objective of the research presented here could be compared to a prism with three faces: one side would be occupied by a manuscript, the second by a translation and the third by a process of creation. The first face is the manuscript of 114 poems by poet Emily Dickinson translated into Italian by the poet and translator Rina Sara Virgillito (the second face). The five manuscript notebooks were found in August 1996, after the death of the poet, at her home in Bergamo, Italy, by her friend and universal heir, Sonia Giorgi. The translation of Dickinson's poems was the last literary endeavour of Virgillito, which, because of her death, remained unfinished. I have studied the five notebooks during a period of five years, from 1996 to 2001. During this period, a philological analysis and transcription of the notebooks was undertaken with a view to possible publication. They were finally published in Milan in 2002 by the Garzanti Publishing House.

The first step in the analysis to establish the "dossier Virgillito" was to consult the books of Dickinson's poems - both originals and translations - in Virgillito's library, the books the translator read and which contained notes in the margins that recorded the dates of successive readings. The catalogue of the translator's personal library was also examined. This analysis enabled me to trace clearly the phases in the genesis of her translations of Dickinson. It was possible, for instance, to 
Manuscripts and translations: Spaces for creation

observe that in 1956 Virgillito read and made partial notes in the margins of a collection of poems by Dickinson translated into Italian by Guido Errante (1956). Gradually, she started making small notes on verses and on whole poems, and from 1995 onwards she actually began her systematic translation process. The traces she left on the books by Errante (1956, 1964) and Guidacci (1979) and, more often, in the translations by Lanati (1986) constitute a genuine pre-writing explanatory phase. Here, the translator, in a growing climax of interest in the poetics of the American poet, gained more confidence and began shyly to make her own translation of some verses and poems, which, in the end, turned into a systematic translation project involving 114 poems. Indeed, the increase in the marks left in the manuscripts seems to demonstrate that the author, while reading the text, had begun to translate, at first, words and sporadic verses, and then moved on relentlessly from translating verses to stanzas and finally whole poems. This can be observed clearly in the marks left in the books of Campana (1983) and Lanati (1986).

In the second phase of the analysis of the prototext I sought to understand what Virgillito's idea of translating Dickinson was. Virgillito had arrived at the Dickinsonian texts after years of experience as a translator who had translated a variety of works, including translations from various ancient and modern languages. The introductions and the notes written by the author at the time of publication of the translations, as well as reviews and testimonials published on her and her work, were key to helping me rebuild her translational pathway. Before anything else, though, I was able to browse through the books in her personal library for texts that could shed some light on her creative route. In fact, in the catalogue of her library I found only one book on translation theory, namely Roman Jakobson's Saggi di linguistica generale, organized by Luigi Heilmann and published by the publishing house Feltrinelli in Milan in 1976. Although finding this book in her library was not sufficient evidence with which to place the translator within a more prescriptive translational paradigm, which is what Jakobson represented, the discovery nevertheless served at least as a clue of some significance. This is especially true if one considers that in her critical introduction to the translation of Shakespeare's sonnets Virgillito (1988, p. 22) cited exactly a passage of Jakobson's work that justifies her translation criteria. The assumption that Virgillito would not have followed a defined translational paradigm but, on the contrary, that she had instead adapted her translation process to the nature of the text to be translated, to the poetic style itself and to her target audience - and let's not forget that she was a poet herself - is confirmed in a reading of the analysis made by critics who have written about her translations of Shakespeare, BarrettBrowning and especially Dickinson (Bulgheroni, 2002, p. XXII).

In the third stage, I analysed more thoroughly the manuscripts that indicated rather complex preparation. I found inscriptions of dates and even a classification of various attempts at the translation of different 
verses and stanzas on covers or on title pages. These vestiges gave me a glimpse of her work dynamic: Virgillito would write the first version of a poem in one single attempt, then she would immediately read and correct it, later transcribing this corrected version into a manuscript notebook, which later would be reread and "re-corrected". There are no definitive transcriptions of these poems, only temporary ones, as she herself noted on the covers of the first and second books of transcriptions.

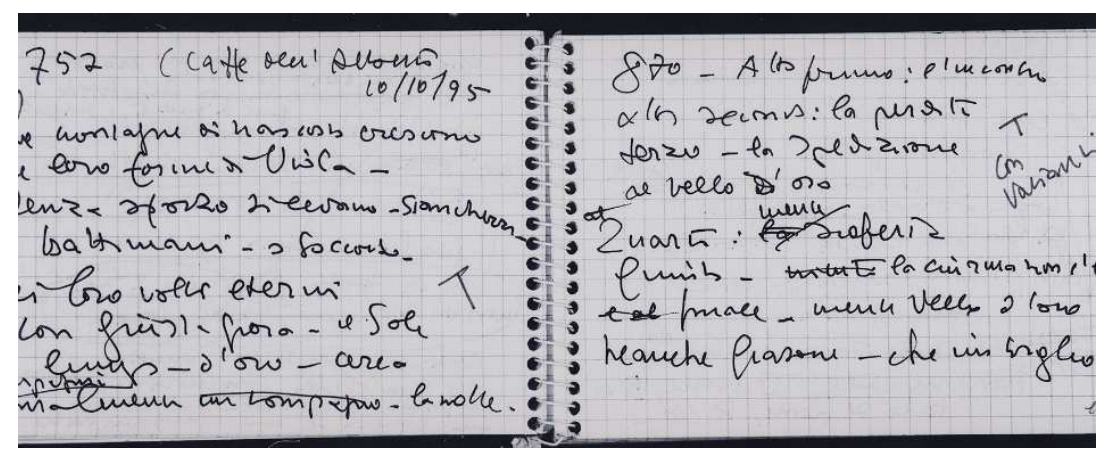

Figure 1. Virgillito, S. (1995). Virgillito's notebook page. FUNDO VIRGILLITO (box 210, first notebook, ff. 20-21). Archivio di Stato di Firenze, Italy

Another interesting fact that emerged from this analysis is that in many cases one was able to find, especially in her calendar book, other new poems alongside these translations. This information confirms another peculiar trait of Virgillito's intellectual and poetic work: her predilection for poetry and translation. In turn it supports the thesis that the two activities occurred in parallel in the life of the Italian poet and, therefore, that for her translation and poetry mutually influenced each other. There is also the suggestion that the translated poem was actually perceived by her as a creation and that it became a part of her poetry.

I propose to use the poem 1247 to exemplify this long and meticulous process of creation. Poem 1247 has, perhaps, been one of her most crafted poems, since there are eight different versions. Here, the main problem that apparently bothered the translator revolved around how to translate the verb to pile. In the first version, Virgillito chooses, at first, the term ammonticchiarsi [to cram up], only to discard it and adopt the verb dilatarsi [to dilate], also discarded and replaced by comprimersi [to huddle]; then, once again, it was altered, as can be seen in the notes in red in the transcription. The verb accumularsi [to gather] is adopted, only to be replaced finally by a verb from an earlier version, comprimersi [to compress]. In eight other versions of the same poem, the question remained open, the translator having resorted to deletions, substitutions and reconsiderations of verbs that had previously been discarded, until, 
Manuscripts and translations: Spaces for creation

after three months, in the eighth version, she confirmed the choice of a verb that had already been tried and tested, the verb comprimersi ${ }^{1}$

\#1

1247

1 < addensarsi >

[[Concentrarsi] come tuono al [suo] nucleo [...].

Virgillito, S. (1995). FONDO VIRGILLITO (box 210, first notebook, f. 39). Archivio di Stato di Firenze, Italy

\#2

1 Come tuono restringersi nel nucleo

Restringersi come tuono al nucleo

addensarsi

concentrarsi $[\ldots]$.

Virgillito, S. (1995). FONDO VIRGILLITO (box 210, first notebook, f. 40). Archivio di Stato di Firenze, Italy

\#3

$\underline{\text { R Riv }} 1247$

ore $18: 30$

1 [Addensarsi come tuono al nucleo [...].

Virgillito, S. (1995). FONDO VIRGILLITO (box 210, first notebook, f. 41). Archivio di Stato di Firenze, Italy

\#4

1 < controll. $>1247$ - 27/10 < addensarsi [sul limite?] >

$<$ nel chiuso $>$

$<$ concentrarsi al nucleo $>$

Come tuono restringersi nel nucleo [...].

Virgillito, S. (1995). FONDO VIRGILLITO (box 210, first notebook, f. 45). Archivio di Stato di Firenze, Italy

\#5

$1247<$ LANATI $>*$

$1<<.<<-27 / 4<$ [restringersi] $>$

$<$ comprimersi >

$<$ [[addensarsi fino al] $]>$

\rangle$\langle($ limite $)\rangle$

$<[$ (comprimersi) nel [chiuso]

5 Come tuono [concentrarsi al nucleo ] [...].

Virgillito, S. (1995). FONDO VIRGILLITO (box 210, third notebook, f. 8). Archivio di Stato di Firenze, Italy

\#6 
Manuscripts and translations: Spaces for creation

$$
\begin{aligned}
& 1<\text { (comprimersi) }><[[\text { nucleo }]]> \\
&<[\text { comprimersi }]><\text { limite }> \\
&<[\text { costringersi] nel }[\text { (chiuso })]> \\
& \text { Come tuono [restringersi nel nucleo] [...]. }
\end{aligned}
$$
Virgillito, S. (1995). FONDO VIRGILLITO (box 210, third notebook, f. 18). Archivio di Stato di Firenze, Italy

\#7

$$
\text { (1247) < 12.1.96> }
$$

1

$$
<\text { limite > }
$$

Come tuono comprimersi nel [chiuso] [...].

Virgillito, S. (1995). FONDO VIRGILLITO (box 210, fourth notebook, f. 10). Archivio di Stato di Firenze, Italy

\#8

$$
\text { (1247) > . > }
$$

1 Come tuono comprimersi nel limite [...].

Virgillito, S. (1995) FONDO VIRGILLITO (box 210, fourth notebook, f. 32). Archivio di Stato di Firenze, Italy

The marks on the sheet, therefore, show an approximation process and also attempts, often unresolved (since the option was often kept open), at generating possible versions, all a priori valid, but none considered definite. This is how such examples confirm the assumption that Virgillito worked, especially in the beginning, instinctively, the first attempts usually having been the most creative ones, and the latter attempts having usually been closer to the source texts. (For reasons of space, other examples are not presented here, but can be checked in Romanelli (2013). It is also noticeable that Virgillito, in spite of revealing her very own poetics during the process of translating Dickinson's poems, usually ended up discarding the versions that led to unique and most surprising effects.

The systematic work and creation method of the Italian poet exemplifies and confirms the thesis that the work of a writer/translator is never closed or completed, but remains unsatisfactory and provisional, even after publication. The analysis of the manuscripts carried out by Virgillito herself, and the analysis made by the geneticist at a later stage, point to the paradox inherent in creation: on the one hand, it is seen as the meticulous work of revision, transcription, rereading and correcting of manuscripts which seems to suggest dissatisfaction on the part of the author/reader/translator with his or her own work; on the other hand, one understands how this very toil is nothing more than an unstable and unpredictable process over which the author does not exercise much 
control. One can also observe that even during some stages of writing, the writer is dominated and guided by the power of words, following an untrodden path - as Robert Frost put it $^{2}$ - witnessed by erasures, by crossroads and by reconsiderations which appear in the manuscript text. The analysis of these manuscripts shows, in fact, that writing can be a really complex and unstable system in which the laws of dispersion and reorganization exist in a state of constant flux. Also, what I intend to highlight here is the fact that from the first translated version Virgillito's manuscripts show how the original version in English is no longer the primary concern of the translator, but rather the development of a poetic and creative discourse in the target language. In other words, the translator focuses on his or her text, on its internal coherence, and not on being faithful to the original text.

\section{Second case: The translations of Dom Pedro II}

The second study used as its point of departure the analysis of the translation manuscripts of Dom Pedro II accidentally found in the Imperial Museum in Petropolis and in the IHGB (Historic and Geographic Institute of Brazil). The results of this research are now also available in a book entitled Dom Pedro II: Um tradutor Imperial (2013), for which Noêmia Guimarães Soares, Rosane de Souza and I were responsible. It is worth mentioning here that as we started this investigation, it was impossible to foresee the magnitude of both the manuscripts available and the intellectual activity and networks of interests and contacts these documents would testify to. As I delved into the rescue, study and dissemination of these documents, I was puzzled by the lack of attention given to them to date, and also to the vast set of data they contain. These documents record the Emperor's translational and intellectual activity, which has hitherto been considered only superficially or adjudged to be a useless occupation of a bored monarch detailing his diplomatic obligations and personal literary desires. Until our analysis began, the manuscripts had received no significant attention nor had they generated any research results.

Despite my still being in the process of studying this material, I am firmly convinced that the aforementioned "judgement" or "attitude" is absolutely unfounded, being frivolous and biased. Indeed, it was based on theoretical and political prejudices and not on any in-depth study of the documents themselves - which might never, or hardly ever, have been read or examined with the attention they deserve. What was at first supposed to be a study of the translation process of the Emperor and intellectual of the nineteenth century has become the discovery and the unveiling of a precise political and cultural project for the establishment of a counter-hegemonic identity implemented through the use of translation as a means of contact and the importation of ideas and out-of- 
Manuscripts and translations: Spaces for creation

reach models (not only European and not only literary). The Emperor's project also aimed to disclose an implicit and unadvertised agenda that conflicted with the Emperor's political responsibilities and with what the Empire actually represented. Let me reveal this by showing you not only the vastness of the material uncovered and the extent of its collection, but also by interpreting the material (partially) in the light of the data revealed by his letters and diaries. I would like to stress that my reading is not that of a historian but that of a geneticist and linguist who considers translation as a cultural phenomenon inserted in and examined from the perspective of a polysystem of influences, models and norms. These factors shape both the system from which this cultural phenomenon originates and the system it generates.

For the purposes of my study, I do not dwell on biographical and historical data already in the public domain, but try instead to draw on this parallel story, which, as I said, remains invisible despite having left consistent marks.

Some of D. Pedro's great passions were foreign languages, literature, translation and lyrics lato sensu. We know this from expressions in several of his own notes or reports by those who knew him and studied his life and work. This dedication to languages was not restricted only to speaking foreign languages but to translating from them into Portuguese; according to notes he made in his personal diary, he also used to compare translations performed by others, such as translations of The Lusiads. These reveal a vast interest in and knowledge of different editions, variations, and studies of the classics of world literature. Only three of the Emperor's translations have been published to date, namely:

- $\quad$ Prometheus Bound, Aeschylus;

- Poems (originals and translations) of D. Pedro II, this being a tribute to him by his grandchildren; and

- Hebrew - Provençal Poetry of the Israeli Comtadin Ritual, printed in Avignon in 1891.

If at first glance, the Emperor seems to have translated the poets he most particularly admired. On closer examination, however - based both on the transcription and analysis of his translation manuscripts and on the reconstitution of the polysystem in which he was included - one finds evidence that translation seems to have been a means of bringing him into contact with leading European and American intellectuals (a point in case being his contemporaries Manzoni, Longfellow, Cesare Cantù and Hugo). Moreover, translation seemed to be a privileged means by which he attempted to establish a political, cultural and religious project in the "new" Brazil (Republican Brazil). The peculiar choice of translations from counter-hegemonic texts in Arabic, Hebrew and Sanskrit, as well as political texts in Spanish and Italian, in addition to the presence of German intellectuals and experts in the Middle East and even a Jewish 
private language tutor in his network of friends, led me to believe that the act of translation also played another important role in his life. In the Emperor's personal diary, one finds notes about these translations and the dates they were made, as in the following excerpts:

Nov. 21 1872, $5^{\text {h }} 1 / 4$. "I had breakfast and will translate from Hebrew." (Alcântara, 1999, p. 344)

[21 de novembro de 1872 "5 $5^{\text {h }} \frac{1}{4}$. Tomei o café e vou traduzir do hebreu"]

Nov. 181876 "After lunch, during recess, I translated the Act of the Apostles with Henning [...]." (Alcântara, 1999, p. 435)

[18 de novembro de 1876 "Depois do almoço, enquanto não se seguia traduzi os Atos dos Apóstolos com o Henning [...]"]

In other excerpts from the diary, one observes that, after writing the first draft of the translation, often aided by an expert in the language and culture of origin, he would have the translation transcribed; but, at times, he would work on the translation again, either before or after submitting it to friends, intellectuals and others, either to present them with the product of his creativity or to receive their admiration, esteem, and feedback about the quality of his work:

Nov. 27, 1890 (5th) [...] 10:45 "Hebrew and Camões. I'm almost finishing the comparison of the German translation of The Lusiads with the original. [...] I read my translation of the Arabic tale from the Thousand and One Nights, [...] As I continued my translation in this empty notebook, I only gave them the notebook which is all scribbled, and I will look for the other one to lend them as well [...]." (Alcântara, 1999, p. 878)

[103/4 "Hebraico e Camões. Estou acabando quase a comparação da tradução alemã dos Lusíadas com o original. [...] Li a minha tradução do árabe do conto das Mil e Uma Noites, [...] Como continuei a minha tradução nesse livro em branco só lhes deixei o livro da minha tradução que está todo escrito e vou procurar o anterior para lhes emprestar também [...]"]

There is also evidence of his sudden awakening with the desire to translate a particular poem, then evidence of a more in-depth study of what he had just translated, that first moment of creative stimulation, and then the transcripts and the dispatch of these translations to friends for 
Manuscripts and translations: Spaces for creation

feedback or a testimony of his work, thus confirming a certain regularity in the Emperor's creative process:

August 6, 1890 [...] “I'm about to translate Schiller's Bell, after having copied the sonnet with today's date to give it to the countess." (Alcântara, 1999, p. 822)

[6 de agosto de 1890 [...] "Vou à tradução do Sino de Schiller depois de ter copiado o soneto com a data de hoje para dá-lo à condessa."]

August 16 [...] 4:45 "I just dictated the copy of my translation of Schiller to Japurazinha." (Alcântara, 1999, p. 828)

[16 de agosto [...] 4h 3/4 "Acabei de ditar à Japurazinha a cópia de minha tradução de Schiller."]

Of all the translations quoted in these pages of his diary, I decided to present here the translation from Italian to Portuguese of Alessandro Manzoni's ode "Il Cinque Maggio". The prototext of this research is composed of digitized manuscripts and includes letters from Manzoni to D. Pedro II and vice versa (15 in total), a copy of the original manuscript in Italian, one version with D. Pedro's translation of the poem "Il Cinque Maggio" bearing D. Pedro's signature, and another manuscript version of the Baron of Barra translation.

In 1851 D. Pedro II penned his first draft of the translation of Manzoni's ode, which he takes up again in 1869 and in 1871; but only the last version was found in the Imperial Museum in Petrópolis. The manuscripts of the earlier versions have not been found yet, only some transcriptions or indirect notes, found in the books of researchers Medeiros e Albuquerque (1932, pp. 42-47) and Alessandra Vannucci (2004, pp. 79-80).

However, very recently, I have found a publication from 1885 , edited exactly on 5 May, the 64th anniversary of the death of Napoleon, to whom the ode was dedicated. This publication included three translations published in Rio de Janeiro: one by José Ramos Coelho, one by Dom Pedro de Alcântara (as stated in the book) and the third one by the Viscount of Porto Seguro, F. A. Varnhagen. This publication provides us with a first descriptive analysis. The book entitled Cinco de Maio: Ode Heróica de Alexander Manzoni e Três versões em Português [May Fifth: Heroic Ode by Alexander Manzoni and Three versions in Portuguese] contains a prologue by M.O., an unidentified author. Both in the prologue and in the explanatory notes to the translation made by the Emperor there is important data on the critical acclaim of the translation by D. Pedro, his recognition by the international community of scholars he longed to 
become a part of, and the confirmation of the partial judgement made by biographers of the quality of D. Pedro's translation activities. The prologue is a negation of all that $\mathrm{D}$. Pedro had done throughout his reign, both as a politician and as a scholar and translator. It therefore seems obvious that Medeiros's preface had an ideological purpose which bears only a historiographical value for us today. I do not want here to defend fully the deeds of D. Pedro II; instead I judge his literary and translational output and the role it played in imperial politics. I do so by applying empirical data and not simply some unjustified a priori assumptions, as Medeiros has done.

Manzoni's ode was immediately acclaimed by the Italian and European critics, and translated by significant names in world literature such as Goethe and Lamartine. It is worth mentioning that as early as $1882 \mathrm{Mr} \mathrm{C}$. A. Meschia had gathered the different versions of the ode he had come across in an elegant volume, which he entitled Ventisette traduzioni in varie lingue del Cinque Maggio di Alessandro Manzoni. This volume included the Emperor's poem. It is considered by Meschia, in a letter he exchanged with D. Pedro, to be one of the best in the collection:

\author{
"Majesty, \\ I only fulfill my duty to lend \\ Your Majesty a copy of the compilation \\ of 27 translations into different languages \\ of Il Cinque Maggio by Alessandro Manzoni, published by me, \\ since one of the finest contributions that \\ enriches the collection, \\ in the opinion of all, is \\ the one that bears Thy Augustus Name" \\ (Meschia, C. A. (1883 August ninth). \\ [Facsímile of a letter from Carlo Attilio Meschia to D. Pedro II] \\ (MAÇO 189 DOC. 8599). Arquivio Histórico de Petrópolis, Brazil \\ [Maestà,/ Non faccio che adempiere un dovere presentando/ alla \\ Maestá Vostra un esemplare della raccoltal di ventisette \\ traduzioni in varie linguel del Cinque Maggio di Alessandro \\ Manzoni, da me/pubblicata, poichè una delle più eccellenti, dalle \\ quali/ la raccolta stessa trae pregio è, a comum giudizio/ quella \\ che porta il Vostro Augusto Nome.]
}

The great mutual admiration between D. Pedro II and Manzoni, and this intellectual and creative relationship, can be witnessed in many letters they exchanged throughout their lives. Among these letters there is, by the way, a confirmation not only of the translation but also a detailed discussion they entertained about their creative process. The stanza they discuss in the letter of 15 April 1853, which was also presented in varying translations in some foreign editions and which Manzoni and D. Pedro 
Manuscripts and translations: Spaces for creation

had considered doubtful, is presented here alongside two other versions in Portuguese, thus hinting at an attempt at a descriptive analysis.

Table 1. Descriptive analysis of the stanza of the ode "Il cinque Maggio"

\begin{tabular}{|l|l|}
\hline Francisco A. de Varnhangen & José Ramos Coelho \\
\hline $\begin{array}{l}\text { O procelloso e trepido } \\
\text { Gosar de vastos planos, } \\
\text { A um reino entre os humanos } \\
\text { Logrou feliz, com prêmios } \\
\text { Insanos de idear. }\end{array}$ & $\begin{array}{l}\text { O procelloso e trepido } \\
\text { Prazer d'uma alta empreza, } \\
\text { A ância de um peito indomito } \\
\text { Que sonha a realeza, } \\
\text { E a ganha, e alcança um prêmio } \\
\text { Que era loucura esp'rar, }\end{array}$ \\
\hline $\begin{array}{l}\text { Pedro de Alcântara } \\
\text { O procelloso e trepido } \\
\text { Prazer d'um grande plano, } \\
\begin{array}{l}\text { A ância de quem indomíto } \\
\text { E o é; e ganha um prêmio, } \\
\text { Que era mania esp'rar; }\end{array}\end{array}$ & $\begin{array}{l}\text { La procellosa e trepida } \\
\text { Gioia d'un gran disegno, } \\
\text { L'ansia d'un cor che indocile } \\
\text { Serve, pensando al regno, } \\
\text { E il giunge, e tiene un premio } \\
\text { Ch'era follia sperar, }\end{array}$ \\
\hline
\end{tabular}

The options presented indicate D. Pedro's approach to the original Italian text, both in formal terms - respecting almost completely the morphosyntax of the original - and in his identification with the topic addressed by Manzoni, namely, how to deny that the verses of this stanza have not touched him: "The anxiety of the indomitable/ Is fit to be sovereign/ And is [...]" [A ânsia de quem indomito/Serve para ser sob'rano / $E$ o é $[$... J]. Another consideration, though one never mentioned, in the exchange of information between Manzoni and D. Pedro II is the occurrence of the term procelloso, which suffers no alteration in the translated text. The conservative approach regarding lexical choices demonstrates his commitment to the translation norms of his time, which valued loyalty to the original. The analysis of this occurrence was considered an attempt to maintain a high Latinism of restricted range, thus confirming the trend previously indicated that D. Pedro II tried to keep his translation close to the original even if the chosen option was less common than other options in the target language, that is, in the Portuguese of the time. This inclination makes him a 
source-oriented translator, estranging the language of the translation rather than domesticating it.

\section{Final remarks}

The two case studies presented here were chosen not only because they represent the core of my research over the past 10 years, but, above all, because they are outstanding examples of the opportunity to study the translation process empirically, looking at the operating mechanisms from within. In addition, it seemed relevant to show how through case studies it is possible to transfigure methodologies and theories not shared up to the present, namely GC and Translation Studies. These case studies also have the advantage of developing both from the epistemological point of view. As I have tried to show briefly in this article, both GC and DTS espouse a systematic approach that focuses on the process of constructing a discourse, in this case the translation's discourse.

In my researches within the field of Translation Studies over the years, I've been dealing with the search for a proper way to make visible the translator's work. I have found in the genetic approach and more especially in the organization and reconstitution of a translator's genetic dossier my personal way of rendering visible the translation and translator's polysystem. In fact, when I tried to apply this concept to GC, I intended to overcome the lack of visibility of those elements that characterize the translator's work (poetical, social, human interferences) and that constrain it but that disappear in the edited text. Everyone talks about them, everyone knows they exist, but no one, or only a few, has been capable until now of making them visible or concrete. GC and the methodological reconstitution of a translator's dossier (as in Virgillito and D. Pedro II, as I have shown here) made up of notes, drafts, diaries pages, interviews, interchanges between editors and intellectuals, etc., help us to make it more possible and concrete to figure out what a polysystem is made of. This polysystem should include the translator's complexity, his interconnection with endogenetic and exogenetic forces, his geographical transversality, his systematicity, and his capacity to reorganize his internal mechanism, starting from a new external insight. Finally, I think that only with the genetic analyses of the translator's dossier can we effectively study and understand the translation process from within, because only in this way can we make it concrete and accessible to everyone.

\section{References}

Alcântara, P., de. (1889). Poesias (originais e traduções) de S. M. o Senhor D. Pedro II. Rio de Janeiro: Typographia do "Correio Imperial". 
Manuscripts and translations: Spaces for creation

Alcântara, P., de. (1891). Poesias hebraico-provençais do Ritual Israelita Comtadin. Avignon: sn.

Alcântara, P., de. (1907). Prometeu acorrentado. Rio de Janeiro: Imprensa Nacional.

Alcântara, P., de. (1999). Diário do Imperador D. Pedro II, 1840-1890. Petrópolis: Museu Imperial.

Bulgheroni, M. (2002). In lotta con l'angelo. In E. Dickinson (Ed.), Poesie. Tradotte da Rina Sara Virgillito (pp. XXII-XXIV). Milan: Garzanti.

Dickinson, E. (1979). Poesie. Milan: Rizzoli.

Dickinson, E. (1986). Silenzi, a cura di Barbara Lanati. Milan: Feltrinelli.

Dickinson, E. (1997). Tutte le poesie, a cura di M. Bulgheroni. Milan: Mondadori.

Dickinson, E. (2002). Poesie. Milan: Garzanti.

Durand-Bogaert, F. (Ed.). (2014). Traduire. Genesis, 38-14. Paris: ITEM-Université Paris-Sorbonne.

Errante, G. (1956). Poesie. Emily Dickinson. Milan: Mondadori.

Errante, G. (1964). Poesie. Emily Dickinson. Milan: Mondadori.

Fundo Virgillito. Caixa 210. Florença: Archivio Storico di Firenze (Manuscritos).

Hermans, T. (1999). Translation in systems: Descriptive and system-oriented approaches explained. Manchester: St. Jerome.

Jakobson, R. (1976). Saggi di linguistica generale. Milan: Feltrinelli.

Lambert, J., \& Gorp, H. van. (1985). On describing translations. In T. Hermans (Ed.), The manipulation of literature: Studies in literary translation (pp. 42-53). London: Croom Helm.

Meschia, C. A. (1883). Ventisette traduzioni in varie lingue del Cinque Maggio di Alessandra Manzoni. sl: Stabilimento Feliciano Campitelli.

Manzoni, A. (1855). Cinco de Maio. Ode heroica de Alexandre Manzoni e três versões em portuguez. Rio de Janeiro: sn.

Medeiros e Albuquerque (ed.). (1932). Poesias completas de Dom Pedro II. Rio de Janeiro: Editora Guanabara.

Romanelli, S. (2013). Gênese do processo tradutório. Vinhedo: Editora Horizonte.

Romanelli, S., Soares, G. N., \& Souza, R., de (Eds.). (2013). Dom Pedro II: Um tradutor imperial. Tubarão: CopyArt.

Salles, C. A. (1992). Crítica genética. São Paulo: Educ.

Toury, G. (1995). Descriptive translation studies and beyond. Amsterdam: John Benjamins.

Virgillito, R. S. (1988). Introduzione. In: Shakespeare, W. I Sonetti (pp. 7-22). Rome: G. T. E. Newton.

1 There are several types of transcription: in this research the linear type was adopted. This type consists of the typewritten reproduction of a manuscript that transcribes all the elements of the original without being truthful to the topography/layout of the page. Since there is still no agreement on the code to be used, or a specific norm, the following operators were adopted: \# version///? doubtful reading / [//?] doubtful reading of a part or of a word that has been crossed out//?/ illegible word or part/ [/?/] illegible or crossed out word or part/ $<>$ additions/ $>$ additions to the right/ $<$ additions to the left $/ *$ for researcher's 
comments/ [ ] erased/ ( ) substitutes the circled word or part in the manuscript/ $\downarrow$ substitutes what was moved down $/ \uparrow$ substitutes what was moved up/ $\rightarrow$ substitutes what was moved to the right $\leftarrow$ substitutes what was moved to the left.

2 http://www.poetryfoundation.org/poem/173536 